\title{
The use of SI in reporting results in pathology'
}

The Système International d'Unités (SI) is becoming the approved means of expressing information in all branches of science and technology (including medicine) in this country. This affects pathologists in two ways, both in scientific writing and in expressing results on specimens from patients. The medical editorial aspect has been covered by a working party, originally sponsored by the Royal Society of Medicine, and a booklet containing recommendations on units, symbols, and abbreviations will shortly appear.

The application of SI to pathological reports on patients involves the choice of units of measurement and of their method of expression. The changes now recommended involve mainly the nomenclature of units, and conform to those made for other sciences. Changes to units which would involve an alteration in the numerical value of results (such as occurred when $\mathrm{mEq} / 1$ replaced $\mathrm{mg} / 100 \mathrm{ml}$ for electrolytes) have not been proposed now, and would have to be introduced more gradually with interdisciplinary agreement of the medical profession in general. Here unfamiliarity could lead to lethal misunderstanding.

SI has six basic units: metre, kilogram(me), second, ampere, kelvin, and candela, supplemented by the radian and steradian, and with the addition of the mole. All other units are derived from these.

\section{Multiples and Submultiples}

Decimal multiples and submultiples of units are formed by the use of prefixes, according to the Table.

\begin{tabular}{llllll}
\hline Multiple & Prefix & Symbol & Submultiple & Prefix & Symbol \\
\hline $10^{12}$ & tera & $\mathrm{T}$ & $10^{-1}$ & deci & $\mathrm{d}$ \\
$10^{9}$ & giga & $\mathrm{G}$ & $10^{-2}$ & centi & $\mathrm{c}$ \\
$10^{6}$ & mega & $\mathrm{M}$ & $10^{-3}$ & milli & $\mathrm{m}$ \\
$10^{3}$ & kilo & $\mathrm{k}$ & $10^{-6}$ & micro & $\mu$ \\
$10^{2}$ & hecto & $\mathrm{h}$ & $10^{-9}$ & nano & $\mathrm{n}$ \\
10 & deca & da & $10^{-12}$ & pico & $\mathrm{p}$ \\
& & & $10^{-15}$ & femto & $\mathrm{f}$ \\
& & & $10^{-18}$ & atto & a \\
\hline
\end{tabular}

Compound prefixes should not be used. Thus $10^{-9} \times$ metre is nanometre $(\mathrm{nm})$, not millimicrometre $(\mathrm{m} \mu \mathrm{m})$.

${ }^{1}$ Report of a working party set up by the Royal College of Pathologists.
In general multiples and submultiples are used in steps of $10^{3}$.

All typewriters should have one key changed to $\mu$ (cost about £2).

\section{Expression of Large Numbers}

Because in many countries the comma is used for the decimal point, the comma should be avoided as the spacer in expressing large numbers. Instead (if there are more than four digits) groups of three digits are to be separated by a half-space. Thus, one million five hundred thousand is $1.5 \times 10^{6}$ or 1500000 .

For high or low values of units, it is preferable to use an appropriate prefixed unit, if possible ensuring that the resulting numerical value is between 0.1 and 1000 . Thus $50000 \mathrm{~g}$ is better expressec $: ; 50 \mathrm{~kg} ; 0.000075 \mathrm{~m}$ is better expressed as $75 \mu \mathrm{m}$ and not as $0.075 \mathrm{~mm}$.

It is suggested that red cell counts should be expressed as $x \times 10^{6} / \mu \mathrm{l}$ (range of $x$ about $0 \cdot 5-10 \cdot 0$ ), and platelet counts as $y \times 10^{4} / \mu 1$ (range of $y$ about 0.1-200). However, strict adherence to the principles of SI might be thought to imply expression of platelet counts as $z \times 10^{3} / \mu \mathrm{l}$ (range of $z, 1-2000$ )?

\section{Symbols for Units}

These are in upright type, without a full stop, and do not alter in the plural. A capital letter is used only in the symbol for units, such as $\mathrm{Ci}$ (curie), which are derived from proper names (Curie).

\section{MULTIPLE UNITS}

\section{Powers}

'Squared' and 'cubed' are to be expressed as numerical powers and not by abbreviations. Thus the area square centimetre is $\mathrm{cm}^{2}$ not $\mathrm{sq} \mathrm{cm}$.

\section{Combination of units}

When only two units are concerned, one being divided by the other, the divider, 'per', may be represented by the single solidus $(/)$ or by the use of negative powers. Thus 'millilitres per square metre' is $\mathrm{ml} / \mathrm{m}^{2}$, or $\mathrm{ml} \mathrm{m}^{-2}$. 
Use of more than one solidus must be avoided as this leads to mathematically ambiguous statements: not $\mathrm{ml} / \mathrm{m}^{2} / \mathrm{h}$, but $\mathrm{ml} \mathrm{m}^{-2} \mathrm{~h}^{-1}$ or $\mathrm{ml} / \mathrm{m}^{2} \mathrm{~h}$.

IMPERIAL UNITS

These are to be abandoned. If it is ever necessary to quote measurements made in Imperial units, then the SI (metric) measurement derived by an appropriate conversion factor must also be given.

\section{Special Applications to Pathology}

\section{LENGTH}

The basic unit is the metre $(m)$.

The ångstrom unit $(\AA)$ should not be used, and the measurement should be converted to nanometres $\left(1 \AA=10^{-1} \mathrm{~nm}\right)$.

The micron $(\mu)$ as a name for a unit of length $\left(10^{-6} \mathrm{~m}\right)$ is obsolete: the correct name for this unit is the micrometre $(\mu \mathrm{m})$.

\section{VOLUME}

The basic unit is the cubic metre $\left(\mathrm{m}^{3}\right)$.

Working unit is litre (1), which is an alternative name for the cubic decimetre $\left(\mathrm{dm}^{3}\right)$.

In pathology multiples and submultiples of the litre (including, for example, $100 \mathrm{ml}$ ) should be used for all measurements of volume.

The lambda $(\lambda)$ as a name for a unit of volume $\left(10^{-6} 1\right)$ is obsolete: the correct name for this unit is the microlitre $(\mu \mathrm{l})$.

Per cent $(\%)$ means 'per hundred parts of the same'. Thus 'mg \%' means milligrams per hundred milligrams', and must never be used to mean 'milligrams per hundred millilitres', which differs by a factor of the order of one thousand.

MASS

The basic unit is the kilogram (kg); working unit is gram (g). [It has recently been agreed that the spellings kilogram, gram, etc, are accepted for use in Britain.]

Multiples and submultiples are of the gramme and not of the kilogramme.

The gamma $(\gamma)$ as a name for a unit of mass $\left(10^{-6} \mathrm{~g}\right)$ is obsolete: the correct name for this unit is the microgram $(\mu \mathrm{g})$.
ENZYMES

There is as yet no agreed system of units applicable to all enzymes measured in pathology. Care must be taken, unless a familiar method and unit are being used, strictly to define the unit quoted.

\section{PRESSURE}

The basic unit is the newton per square metre $\left(\mathrm{N} / \mathrm{m}^{2}\right)$. The alternative name for this unit is the Pascal (Pa).

Conventional units are millimetres of mercury $(\mathrm{mmHg})$, centimetres of water $\left(\mathrm{cmH}_{2} \mathrm{O}\right)$.

In pathology, as in medicine in general, pressure measurements made on the height of a liquid column will continue to be so expressed.

Conversion factors (at stp): $1 \mathrm{mmHg} \approx 133$ $\mathrm{N} / \mathrm{m}^{2}, 1 \mathrm{cmH}_{2} \mathrm{O} \approx 98 \mathrm{~N} / \mathrm{m}^{2}$.

\section{TIME}

The basic unit is the second (s). Other working units are minute (min), hour (h), day (d), year (a).

\section{THERMODYNAMIC TEMPERATURE}

The basic unit is the kelvin $(\mathrm{K})$ not degree Kelvin $\left({ }^{\circ} \mathrm{K}\right)$.

The working unit (customary temperature) is the degree Celsius $\left({ }^{\circ} \mathrm{C}\right)$.

\section{AMOUNT OF SUBSTANCE}

The basic unit is the mole (mol). The mole replaces the gram-molecule, gram-ion, gram-equivalent, etc.

It is recommended that the use of the equivalent and its submultiples (eg, milliequivalent) be abandoned. Where monovalent ions are concerned $\left(\mathrm{eg}, \mathrm{Na}^{+}\right), 1 \mathrm{mEq}$ is numerically identical ? to $1 \mathrm{mmol}$, and their analytical results should therefore be expressed as $\mathrm{mmol} / 1$ or $\mathrm{mmol} / \mathrm{d}$ etc. It is suggested that, in expressing analytical results, extension of the mole as a unit to nonmonovalent ions such as calcium, or to nonionic $\frac{\text { 의 }}{3}$ substances such as glucose, should be deferred $D$ until clinicians become familiar with this new unit. At that time both units will be used until the $N_{\mathscr{O}}$ new units become familiar. The mole system is inapplicable to substances of ill defined molecular weight, or to mixtures.

$M$ is not the symbol for the amount 'mole', but for the concentration 'molar' $(\mathrm{mol} / \mathrm{l})$. If there is $\bullet$ any possibility of confusion, $\mathrm{mol} / \mathrm{l}$ should be $\mathbb{D}$ used. 